\title{
Cleft Jaw
}

National Cancer Institute

\section{Source}

National Cancer Institute. Cleft Jaw. NCI Thesaurus. Code C124511.

A cong enital abnormality consisting of clefting in the jaw, which results from incomplete fusion of the embryonic mandibular prominence. 